\title{
A VIEW ON GENDER DISCRIMINATION AND WOMEN'S DEVELOPMENT IN INDIA
}

\author{
A. NAFEESA BEGUM ${ }^{1} \&$ DR. G. BRINDHA ${ }^{2}$

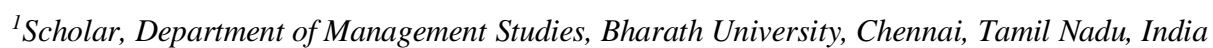 \\ ${ }^{2}$ Professor \& Head, Faculty of Management Studies, Dr. Mgr Educational and Research Institute University,
}

Chennai, Tamil Nadu, India

ABSTRACT
Gender is a common term where as gender discrimination is meant only for women, because females are the only victims
of gender discrimination. Females are nearly 50 percent of the total population but their representation in public life is
very low. Recognizing women's right and believing their ability are essential for women's empowerment and development.
This study deals with gender discrimination in India, its various forms and its causes. Importance of women in
development, legislation for women and solution for gender discrimination are also discussed in this paper.
KEY WORDS: Gender Discrimination, Women's Development, Legislation for Women, Education, Employment,
Economic Independence, Empowerment, Decision Making \& Self Confidence

Received: Apr 28, 2020; Accepted: May 18, 2020; Published: Jul 03, 2020; Paper Id.: IJMPERDJUN2020183

\section{INTRODUCTION}

Gender is a common term where as gender discrimination is meant only for women, because females are the only victims of gender discrimination. Gender discrimination is not biologically determined but it is determined by socially and the discrimination can be changed by the proper and perpetuate efforts. Denial of equality, rights and opportunity and supplement in any form on the basis of gender is gender discrimination. Half of the world's population is females. They are doing two-third of work of the total work in the world but received only one-tenth of the world's total income ${ }^{1}$. Nearly two-third of the women is illiterates and they have possessed only one percent of the total world's assets. In the world only one-fourth of the families are headed by female. India is a male dominant society and gender discrimination is customised habitually.

\section{DISCRIMINATIONS}

From birth to death females are facing lots of discrimination against them. Some of them are,

- Abortion of female gravida with the help of scanning. [?

- Feoticide (By giving liquid extract from cactus / opuntia, giving raw paddy to new born female baby, by pressing the face by pillow or by breaking the female baby's neck) [?

- Not giving enough and nutritious food

- Not allowing to go to school (Denial of education) [?

- Not giving needy health care while in ill health [? 
- Early marriage ?

- Eve teasing, Rape and Sexual harassment ?

- Dowry 目

- Divorce,

- Destitution even for silly or without any reason

\section{Causes of Gender Discrimination}

The causes of gender discrimination are ?

- Educational backwardness ?

- Caste ?

- Religious beliefs ?

- Culture ?

- On the name of family history ?

- Low income ?

- Unemployment ?

- Society 目

- Family situation and ?

- Attitudes

Like male or even above them female plays important role in the family and national development. But her contribution is not recognized by the male dominant society.

\section{IMPORTANCE OF WOMEN IN DEVELOPMENT}

Females are nearly 50 per cent of the total population but their representation in public life is very low ${ }^{2}$. Woman continues to bear the major load of the household work. Her primary role is often viewed by the society as housewife. In cardinal goals of democracy "of the people, by the people and for the people" cannot be pontifically accomplished if the female population remains out of political empowerment ${ }^{3}$. Subordination of women in society acts a structural constraint to their participation in political activities. This constraint operates more or less for all classes and communities of women. Prevalent culture which is very complicated and often decisions are taken behind the scene may be regarded as another constraint in this regard. Recognising women's rights and believing their ability are essential for women's empowerment and development. Females should realize their own capabilities and potentials which will strengthen their self image and foster them with confidence to take action in life. Political empowerment does not imply just a right to role silently but to discuss, share and empower politics by knowing its pros and cons and thereby to influence policies and decision making. Empowering women is the basic to the basics of human rights where she wants neither to beg for power nor search for power hierarchy to exercise 
power against others. On the contrary she demands to be accepted as human first of all. She as a person in command of herself and for that necessarily all the resources physical, social, economical, political, cultural and spiritual to be equally accessible to her, are prerequisites for considering the whole question of empowerment ${ }^{4}$. Indian society is inherited with male chauvinism but now the society has started to realize women's importance and has being accepted women's empowerment, women as an active agent for development, participation in and guiding their own development.

\section{LEGISLATION FOR WOMEN}

In India, several laws, legislations, policies and institutional reforms have been enacted to carry out the gender action plan for the development of women. Legislation is an important instrument for bringing about a change in the unequal economic and social status in India. In pre-independent India, few laws were passed in response to social demands and on the basis of humanitarian consideration. They are Bengal Sati Regulation Act of 1829 and similar Anti-Sati laws in Madras and Bombay, Hindu Widow Remarriage Act 1856, the Hindu Women's Right to Property Act in 1937, (The Muslim Personal Law) the Shariat Act 1937 and the Dissolution of Muslim Marriages Act 19397. After Independence, there have been important changes in legislation and litigation which have facilitated the increased participation of women in political activities as well as in the socio-economic development activities and the increase appear to be more likely at the lower level than at the highest centres of decision making. ${ }^{7}$ Article 14 of Indian Constitution says that the state shall not deny to any person equality before or equal protection of the law, Article 15 says that no women can be discriminated against on the ground of sex, Article 15 (3) emphasis that the state shall make special provisions for women and children and Article 16 provides equality of opportunity in matters relating to employment by the state. In Article 39(a) emphasis that the citizens men and women equally, have the right to an adequate means of livelihood, in Article 39(d) it says that the state should secure equal pay for equal work for both men and women and in Article 34 it provides that the state shall make provision for securing just and humor humane for work and for maternity relief. The 73rd and 74th Amendments of Indian Constitution in 1993 are the milestone in the history of India, which provides lot of powers for the local bodies. It paves the way for decentralisation, empowers the poor people as well as women. According to these amendments not less than one third of the seats, meant for direct election of members at each tier of Panchayats are to be reserved for women and not less than one-third of the seats of chairperson at any level reserved for women.

\section{DEVELOPMENTS IN INDIA}

The most deep-rooted forms of gender inequality had been built into the structure of traditional Indian society. Through gender inequality exists a large measure in the society under different dimensions for long time, its importance has grown in the recent times only. In the traditional society the inequality between males and females existed to a large extent. Women were looked down socially, economically and politically. Women became scope goats of many traditions and customs. She was brutally killed in the name of Sathi. The practice of child marriage, Kanyasulkam, Prostitution was taken it granted by society and a woman has no voice what so ever for centuries together. Women's role was restricted to domestic life especially kitchen work and bearing and rearing of children. She has no place in economic and political activities. Girl children were discriminated in terms of basic necessities of life such as food, clothing and shelter. Woman is the last person in the family to eat. She is the person who does all types of menial jobs. There is no respect for her work. Most of the women's work outside the domestic front is restricted to agricultural labour activity (in agriculture) and unorganized activities in urban sector. The census of India did not consider their work while counting the number of economically active persons in the country for quite a long time. The Government of India has taken several measures and also making endeavourer to hoist the 
status of women in the society in order to promote equality of men and women ${ }^{7}$. The different plans, programmes, and policies have laid emphasis on women empowerment and raising the economic, educational, health and political participation of women to match with that of men. The draft national policy on empowerment of women envisages

- To setup councils at the national and State levels to review the implementation of the recommendations of the national and State Commissions for women.

- The centre and State to draw up time bound action plans to translate this -policy into concrete action in consultation with the Central and State Commissions for women.

- Every ministry at the Centre and the State is obliged ensure equal flow of benefits in physical and financial terms to Article 15 of the constitution prohibits any discrimination on grounds of $\operatorname{sex}^{5}$. The directive principles of State policy also urges that the State shall direct this policy towards securing an adequate means of livelihood for women and ensuring equal pay for equal work for both men and women. In the sixth five year plan emphasis was laid on raising the employment status of women. The seventh plan emphasized the need for human resource development in women. The eighth plan aims at enabling women to function as equal partners and implement social legislation for women effectively. The ninth plan has identified empowerment of women as an objective. The tenth plan also emphasis on women development. ${ }^{6}$ The formulation of the national commission for women (N.C.M.) and the idea of setting of a national council for empowerment of women are encouraging steps in this direction. Also different state governments are also implementing several development measures for women's health in general and reproductive health in particular. The lack of sex education among adult girls and re-productive health education among the married women are also cause of many preventable diseases. Empowering women regarding the own reproductive health care and effecting accountability of men towards women's re-productive health are important for promoting women health status in the society. Now with the efforts of national and international organizations several laws were passed and some laws were changed. But still women continue to suffer from many social and economic and political disadvantages, since the attitudes did not change as fast as the change in laws. Gender issues are ideologically motivated and need a change in mindset in terms of attitudes and behaviour of both men and women of all dimensions.

\section{SOLUTION FOR GENDER DISCRIMINATION}

Various movements, programmes are being carried out by the Government, voluntary organizations and by lot of social activities for women's development and against the gender discrimination. To solve the gender discrimination problem the E4 SD factor would be very useful. Factors are

\section{Education}

Education develops the skills, imparts knowledge, changes the attitude and improves the self confidence. It provides employment opportunity and increases income. Hence educating women is the prime factor to combat gender discriminate and for the upliftment of women. Not only the female, the society must be educated to give equal right for female.

\section{Employment}

Employment gives the income and improves the economic position of the women. Employed women are given importance 
by the family members. Employment gives the economic independence for the women.

\section{Economic Independence}

In India, mostly, women in the young age - depends her father, in the middle age- she depends on her husband and in the older age - depends on her son. Woman always depends on somebody for her livelihoods hence, independent in economical aspects are imperative for women's development. Economic independence will free the women from the slavery position and boost the self confidence. Economic independence of women also helps in the national economic development.

\section{Empowerment}

Empowering women with the help of laws, education and employment will make the society to accept the women as an equal gender like male. Female also has all the potential and empowering women will help to use her full capability and mitigate the economic dependency of women.

\section{Self-Confidence}

Due to prolonged supplement, Indian women, an especially uneducated and unemployed woman hasn't had the selfconfidence. Women need self confidence to fight against all the atrocities against her and to live self esteemed life. Hence, boosting the morale and self confidence of the women, is the key to eliminate the inferior complex of her.

\section{Decision Making}

Even in the family as well as in the society the decision making power of women is denied. Mostly males make the importance decision in the family and in the society. This makes women as voice less and destroys herself confidence and she feels less important in the family as well as in the society. So, to end gender discrimination women must empower with decision making power.

\section{CONCLUSIONS}

The paper has broadly discussed the issue of gender inequality, women empowerment and reproductive health among women in India. The measures under taken by the international and national organizations to improve the status of women in India were discussed at length. There is a good correlation between gender inequality and reproductive health of women.

The sex ratio is very low in India as compared to many developing countries and most of the advanced countries. The high maternal mortality, infant mortality, child mortality foeticide, infanticide, abortion, low age of marriage social stigma associated with marriage, son preference are responsible for low sex ratio in India. Also under counting of women associated with many social factors is one of the main reasons for low sex ratio in the country. The Social factors, such as, illiteracy, ignorance, the economic factors such as low wage, unemployment under employment and political factors such as, low participation of women in the elections and other elected bodies are also equally responsible for gender inequality in the country.

Empowerment is only effective answer to oppression, exploitation, injustice, and other melodies of society. The idea of empowerment contains exciting possibilities. It is a wide term with no specific meaning. The term is very vogue and is more a context driven rather than theory driven. It is about social transformation. It is about the people rather than politicians. It is about power, although the concept of power contained in it is generally left unspecified. Empowerment is both a means to an end and an end in it self. The focus on empowerment has given a new emphasis to the building of 
economic and social capabilities among individuals, classes and communities. It is theories of social change in particular, a change from a hierarchical to and egalitarian type of society. It is based on democratic society, which is based on recognition of equal rights to all individuals in its place. Empowerment appears to be an alternative path for dismantling the old structure and putting new one in this place. Empowerment is to change the society through re-arrangement of the power. So there is a need for empowerment through civic, political and social rights of citizens. Gender empowerment measure is a measure for women development. It measures gender inequality in a society. India ranks 86 out of 175 countries in the world, as far as gender empowerment is concerned. The measure indicates whether women are able to actively participate in economic and political life. It measures the gender inequality in basic capabilities of women. It focuses on gender inequality in the key areas of social economic political scenario. The lack of access to land, to credit, better employment opportunities, handicaps women's ability to free from poverty; Poverty is more among women as compared to men. When women are disproportionately poor, they are dis-empowered and bounded by strains of productive work, the birth of children and other household and community responsibilities.

Ethical clearance- Nil (permission granted to send for publication by the bharath university research committee)

\section{Source of funding- Self}

\section{Conflict of Interest - Nil}

\section{REFERENCES}

1. Sherman D, Alper W, WolfsonA Seven Things can do to Reduce. Journal of South African Institute of People Management2016$24(3): 8-11$

2. Allen, N.J. and Meyer, J.P. The measurement and antecedent of affective, continuance and normative commitment to the society. Journal of Psychology, 2011-v63, pp. 1-18.

3. Sumadsad, Concepcion, and Ariel Tuazon. "Gender and Development (GAD) Awareness in a Higher Education Institution." International Journal of Educational Science and Research (IJESR) 6.3 (2016).

4. Beck, S. 'What Strategies to Keep Them In. American Lawyer Media L.P., 2015- v5, i2, pp. 23-27.

5. Maertz, C.P., Jr., \& Campion, M.A. 25 years of gender discrimination research: A review and critique. International Review of Industrial and Organizational Psychology, 2008-13, 49-81.

6. Manimekalai, G., and S. Kavitha. "A Study on Bussiness Opporunities for Women Entrepreneurship in Textile Industry. "International Journal of Textile and Fashion Technology (IJTFT) 4. 6, Dec 2014, 1-4

7. Feldman, D. The Dilbert syndrome: How cynicism about ineffective management is changing the nature. American Behavioral Scientist, (2000).43, 1286-1301.

8. Griffeth, R.W., Hom, P.W., \& Gaertner, S. A meta-analysis of antecedents and correlates of Female turnover: Update, moderator tests, and research implications for the next millennium. Journal of Management, 2015-26, 463-488.

9. Hque, Ubaida. "Contribution of Women Entrpreneurs in SMEs Amoung SAARC Countries." International Journal of Humanities and Social Sciences (IJHSS) 6.6 (2017).

10. Government of India, 2008, “Eleventh Five Year Plan (2007-2012), Vol. II, New Delhi, Planning Commission.

11. Mallikarjuna, K. G., and N. T. K. Naik. "Indicators of Women Economic Empowerment." International Journal of Humanities and Social Sciences (IJHSS) 3.3 (2014): 67-74. 
